\title{
The role of public-private partnership in ensuring the economic security of the state
}

\author{
Mikhail Kozin ${ }^{1}$, Galina Pyrchenkova ${ }^{2}$ Elena Radchenko ${ }^{1, *}$ \\ ${ }^{1}$ Federal State Research Institute of the Federal Penitentiary Service of the Russian Federation, \\ Moscow, Russian Federation, 125130, Moscow, Narvskaya str., 15 A \\ ${ }^{2}$ Academy of Management of the Ministry of Internal Affairs of Russia, Moscow, Russian Federation, \\ 125171, Moscow, Z. and A. Kosmodemyansky str., 8
}

\begin{abstract}
According to the latest World Bank estimates, today the Russian economic system is in the tenth place in the global economic space [1].A successful solution to the problem of ensuring economic security of the state in the context of the growing role of economic factors that determine the need for more efficient spending of the state budget is determined, first of all, by the presence of an appropriate regulatory legislation and scientific and methodological support. The formation of a new applied methodology for ensuring the economic security of the country during the implementation of public-private partnership projects is a priority in the study. A distinctive feature of the approach to ensuring economic security in the implementation of public-private partnership projects is that they maximize the possibility of obtaining a generalized assessment of the implementation of promising public-private partnership projects, taking into account the adopted restrictions on the level of economic security [2]. To date, the Russian Federation has a certain production potential, which must be developed and effectively promoted. All this necessitates the development of theoretical, legal and organizational foundations, as well as managerial mechanisms aimed at improving the economic security of the state. The purpose of this study is to study the economic interaction of the state and business to ensure the economic security of the Russian state using financial and economic indicators.
\end{abstract}

\section{Introduction}

In the context of a sharp deterioration of relations with Russia, due to the events in Ukraine, the Syrian Arab Republic, Western countries and the United States actually declared an information war and imposed economic sanctions aimed at weakening the Russian economy and changing the political course [3]. Accordingly, ensuring national security is impossible without a comprehensive consideration of the political, legal, economic, scientific and technical, spiritual and moral, information, military and other capabilities of society and the state [4]. At the same time, the achievement of the required state of national security presupposes the existence of an appropriate system of ensuring economic security.

\footnotetext{
*Corresponding author: helenr2003@mail.ru
} 
This system includes norms, means, ways, methods by which subjects influence dangers and threats to achieve the stated goals [5].

Studies have shown that over the past century and a half there have been three main approaches of theoretical economists to what should be considered the main threat to the national economy:

1) the cameralistic concept of protecting foreign economic security (exists from the middle of the 19th century), later revived by left-wing radical economists (the last third of the 20th century);

2) Keynesian concept of protection against internal macroeconomic threats (second third of the twentieth century);

3 ) the institutional concept of protection against administrative barriers (end of the twentieth century).

Understanding the main threat to national economic security and methods of struggle for national economic security have been developed since the 1840s by F. Liszt; 1970s by R. Prebish, A. Emmanuel, I. Waller-Stein.

It is necessary to pay attention to the concept formulated back in the 1930 s by the English economist J. Keynes. He believed that the main threat to the national economy is not competition of foreign goods, but unemployment and economic depression. Therefore, it is necessary for the state to manage economic activity through state orders and subsidies, as well as through regulation of the money market and even direct administrative (institutional) control over competition.

In addition, in accordance with the institutional concept of E. de Soto, the main danger to national economic security is institutional barriers in the form of imperfect legislative norms or the possibility of not observing them. The elimination of institutional barriers to national economic security consists in the adoption of new legislative norms, the content of which is in line with the norms of economic democracy, and the creation of institutions to monitor the proper implementation of these legislative norms.

In the new strategy of national economic security of Russia there have been changes in the set of indicators characterizing the level of national economic security. This became possible because, firstly, the criterion values of economic security indicators currently used in the scientific literature, as a rule, are some average results of calculations for a large group of the most developed countries of the world. In this regard, these limit values cannot be universal as applied not only to Russia, but also to other countries. Therefore, when comparing with the data for our country, at present they have the nature of a set of indicators signaling the dynamics and extent of the lag for certain positions [6].

Considering the national interests in the field of strengthening the economic security of the state while implementing the interaction between the state and business, special attention is recommended to be paid to public-private partnership instruments (hereinafter PPP). In most countries, the government is a large customer, ranging from basic consumer goods to high-tech equipment [7].

Today, PPP instruments are used in many countries. Recently, countries such as South Korea and China have begun to show interest in solving the socio-economic problems of the state with the help of PPPs.

Scientists and economists made an important contribution to the development of the theoretical foundations of the study of the essence and problems of the development of relations between the state and business in domestic economics: A.V. Belitskaya V.G. Varnavsky, A.M. Vorotnikov, M.A. Deryabin, A.Yu. Zudin, V.A. Kabashkin, A.V. Klimenko, M.V. Klinova, V.F. Ukolov and many others. Studies have shown that analyzing the state of the public sector, many of them came to the conclusion that it is necessary to improve mechanisms for managing state property $[8,9]$. 
Among foreign researchers who dealt with the problems of interaction between business and the public sector we can note the following ones: M. Boult-Spearing, G. Devulf, D. Grims, M. Siemiatycki, N. Farooqi and others [10, 11, 12].

In January 1, 2016, the Federal Law of July 13, 2015 No. 224- Federal law (as amended on July 26, 2019) "On public-private partnership, municipal-private partnership in the Russian Federation and amendments into separate legislative acts of the Russian Federation" came into effect. In accordance with this law, PPP refers to almost any form of business participation in the implementation of the state defense order and any form of state support for such participation [13].

As a result of the analysis of the theoretical foundations of PPPs, the authors conclude that PPPs are a legally binding, co-financing (co-investing) and risk-sharing system of relations between the state or municipalities and legal entities arising from the implementation of projects the subject of which are state and municipal property, as well as services provided by state and municipal bodies, organizations, institutions and enterprises.

In the interests of maintaining the country's economic security, the lack of a single mechanism for implementing PPP projects, according to the authors, can lead to misunderstanding on the part of the public sector. When implementing projects in the field of national security in the absence of a clear mechanism of their realization, it is recommended not to use PPP tools, since the level of uncertainty and costs, as well as the risk of claims, are very high. This process may present a future economic problem in the implementation of PPP projects in the military-industrial complex. PPP projects should be transparent, uniform and strictly regulated.

\section{Materials and Methods}

The need to ensure the economic security of the state has led to the need to create methodological tools for assessing the economic efficiency of project implementation, involving significant investment and a long-life cycle.

Infrastructure projects implemented at the state level are not only commercially oriented, but also socially significant. However, currently there are no generally accepted methods for assessing the effectiveness of PPP projects from the perspective of taking into account the economic reliability of organizations involved in the implementation of PPP projects.

An analysis of the existing procedures on the selection of reliable organizations involved in the implementation of PPP projects showed:

1. The counterparty's choice is exerted by the results of similar work during the implementation of the PPP project.

2. The leading criterion, as a rule, is the minimization of prices.

3. As a rule, a participant is considered as a counterparty, and the opinion and qualification requirements of the customer substantially influence its choice.

4. The selection criteria for each PPP participant are systematized by the following groups: mandatory when choosing a PPP participant, considering the specifics of the organization's production and economic activities, and auxiliary ones which provide control over the performance of the functions of a PPP project participant.

As for the completeness and reliability of the data, concerning the prospective PPP partner, it is advisable to check and analyze the following information:

- extract from the unified state register of legal entities or a notarized copy of such an extract;

- copies of constituent documents on the basis of which a legal entity acts;

- a document confirming the authority of the person to carry out actions on behalf of the participant in the placement of the order; 
- the register of shareholders for the presence of foreign legal entities and individuals in the owners (shareholders, participants) of enterprises;

- availability of a license for the declared type of activity;

- depositing funds as security for the application;

- the availability of financial support for the tender;

- information on the implementation of work similar in complexity and nature;

- information on claims filed against the company for the last 3-5 years, the facts of non-fulfillment of obligations assumed for quality, nomenclature or deadlines;

- information established in the tender documentation.

Assessment of the business reputation of a PPP project participant includes monitoring the organization's qualitative and quantitative potential, the absence of negative information about it from partners, etc., which allow to form a holistic view of the organization under the influence of various external and internal factors and provide additional economic benefits.

The primary requirements also include the presence of a quality management system (hereinafter referred to as the QMS) in accordance with the requirements of ISO 9001. The organization applying for the implementation of the PPP project must meet the requirements for the QMS.

It is also important to take into account the experience in performing similar contracts. Experience in the implementation of similar contracts is understood as the presence of proven, repeated, continuous experience in fulfilling obligations similar to this contract by the potential PPP project participant. The minimum required level of work experience can be set by the customer in the terms of reference / procurement documentation.

\section{Results}

As part of the study of the problems of the role of PPPs in ensuring the economic security of the state, a survey of participants in PPP projects in the Russian Federation was conducted and recommendations were developed. The data obtained show that the interaction of the state with business is considered effective by $60 \%$ of respondents, and $40 \%$ of respondents believe that it is ineffective, pointing to the reasons for the lack of a single body responsible for the interaction of state departments with business participants and problems in the limitations caused by the lack of a regulatory legislation (more than $80 \%$ of respondents).

While answering the question "What changes are required in the legislation to accelerate the promotion of the state and business cooperation?" $60 \%$ of the respondents noted a reduction in the tax rate, $35 \%$ - the provision of subsidized loans to business, $5 \%$ - a decrease in rents.

When considering what requirements to business, all respondents noted: reliability, solvency, absence of unscrupulous suppliers in the register.

The respondents mentioned the restrictions caused by the lack of a regulatory legislation as an example of unsuccessful cooperation (16\%), lack of coordination of economic interests (40\%), and other factors (30\%).

Further research revealed that there is no systematic, grouped for individual user groups, set of relative indicators used in the analysis of the financial and economic state of enterprises (business structures) [14].

Table 1 - Analytical coefficients characterizing the financial and economic reliability of enterprises applying for the implementation of the PPP project

\begin{tabular}{|l|l|l|l|}
\hline $\begin{array}{l}\text { Name of the } \\
\text { indicator }\end{array}$ & $\begin{array}{l}\text { Characteristic of the indicator of } \\
\text { financial and economic reliability }\end{array}$ & $\begin{array}{l}\text { Methodology for calculating the } \\
\text { indicator }\end{array}$ \\
\hline 1 & 2 & 3 \\
\hline
\end{tabular}




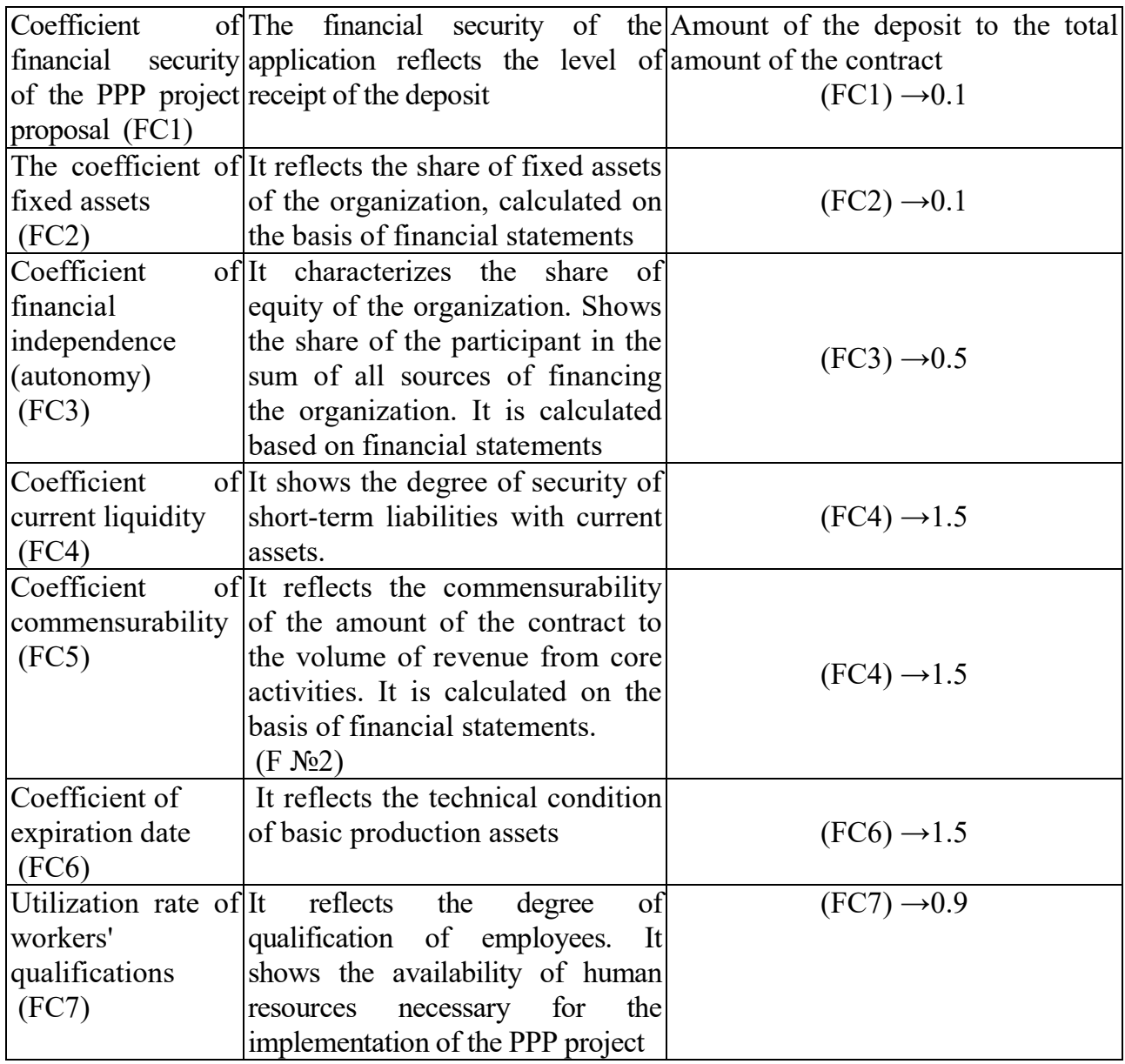

*The table is worked out by the authors

\section{Discussion}

There is currently no methodology for assessing the ranking of potential enterprises involved in the implementation of PPP projects. A comprehensive solution to this problem can be ensured by applying the methodology for assessing the economic security of potential organizations applying for the implementation of a PPP project. This methodological apparatus should include certain criteria and indicators that reflect the mentioned above areas of assessment.

From the point of view of the state customer, the financial and economic reliability of enterprises applying for the implementation of the PPP project can be estimated by such indicators as: financial security of the PPP application, coefficient of provision with fixed assets, financial independence (autonomy) coefficient, current liquidity ratio, commensurability coefficient, coefficient of expiration date, utilization rate of the qualifications of the workforce.

The above indicators are not complete and encompassing ones, which can give a complete picture of the effectiveness of a project, but even evaluating this set of indicators makes it possible to provide the right choice in favor of a project. At the initial stage it is necessary to work out a mechanism for assessing the economic efficiency and safety of PPP projects. For this purpose, it is proposed to develop a unified monitoring system for regularly assessing the effectiveness of PPP projects. 
It should be noted that in some countries quantitative and qualitative indicators are taken into account. When conducting a qualitative analysis, an assessment of the appropriateness of using the PPP model is used. The criteria for such funding are clearly defined in a number of countries. Quantitative analysis involves comparing the price-performance ratio of a PPP project. The implementation of such a project is carried out through traditional public procurement, based on the application of the Public Sector Comparator methodology (calculating the price of a similar project through direct budget financing).

At the same time, it should be stated that the indicators included in the legal criteria are qualifying, that is, non-compliance with them should certainly lead to rejection of the application without further consideration of the proposals contained therein. Estimates for such indicators can take only one of two alternative values: "meets the terms of the PPP project placement" or "does not meet the terms of the PPP project" [15].

\section{Conclusions}

The unity of the economic space, the presence of a large and diverse domestic market is the most important national treasure of Russia. Its preservation and development, taking into account the production specialization of the regions, is of consolidating importance for the Russian economy.

Russia's national interests in the economic sphere are priority, their implementation is possible only on the basis of sustainable economic development and they consist in ensuring the ability of the economy:

- to operate in expanded reproduction mode;

- to create conditions for achieving the level and quality of life of the population, guaranteeing social peace in the state;

- to preserve, develop and effectively use all types of resources (labor, natural, intellectual, informational, financial, etc.);

- to increase the competitiveness of domestic industry.

Implementation of PPP projects in the framework of ensuring the economic security of Russia will solve the following problems:

- ensuring the technical, organizational and economic conditions for the functioning of the economy in the expanded reproduction mode, taking into account its openness to foreign economic cooperation, while maintaining the ability to promptly and adequately respond to adverse internal and external influences and threats in order to minimize their negative consequences;

- the formation of an effective system of markets and business entities, the creation of conditions for the formation of an effective private owner, integration into the system of world economic relations, the removal of obstacles to business development at the micro level;

- carrying out restructuring of sectors of the economy by improving its organizational and institutional structure, ensuring a reduction in transaction and administrative costs, saving working capital.

- increasing innovation and investment activity and, on this basis, updating and deep modernization of fixed assets, production potential and technologies providing a high technical and scientific level of production and increasing the competitiveness of domestic products, especially with a high degree of redistribution;

- effective and targeted development in all areas of the economy, and, above all, in its real sector, innovative processes as the main source of increasing dynamism of its development. 
- development of regulatory documents that exclude the exit from the control of the state of key areas of production that determine the economic and military security of the state;

- creating the necessary and sufficient state material reserve (capacities and materials) to ensure mobilization needs and strategic reserves of material resources of the Russian Federation for the purpose of counteracting sharp market fluctuations in world commodity and stock markets, eliminating the consequences of emergencies of anthropogenic, natural and environmental nature;

- development of transport, primarily export, infrastructure, ensuring efficient use of the economic potential of the Russian Federation.

- ensuring the adequacy of budgetary resources for the full implementation of its functions by the state, in building up the budget potential in the conditions of its balance and normalization of corporate finances based on:

- creating an optimal tax system that stimulates entrepreneurial, innovative and investment activity, and employment of the population;

- increasing the stability of the banking and financial sector of the economy, eliminating the possibility of systemic crises.

- the use of effective protectionist measures to protect domestic producers from unfair competition from importers of products.

Thus, the proposed set of indicators of financial and economic security of potential organizations participating in the implementation of public-private partnership projects allows to obtain as much as possible a generalized assessment of ensuring the state's economic security, taking into account the adopted restrictions on the level of economic security of the implementation of promising public-private partnership projects.

\section{References}

1. Global Knowledge Partnership. Multi-Stakeholder Partnerships. IssuePaper [electronicresource]. URL: www.globalknowledge.org. (Date of access:12.10.2019).

2. Eva I. Hoppe, Patrick W. Schmitz, The RAND Journal of Economics, 44 (1), 56-74 (2013)

3. G. A. Hodge, C. Greve, Public-Private Partnerships, 67(3), 545-558 (2007)

4. M.N. Kozin, O.A. Ibragimov, Izv. Saratov Univ. (N. S.), Ser. Economics. Management. Law, 16 (2), 172 (2016)

5. M.N. Kozin, R.M. Samatov, Power and economy, 7, 62-69 (2017)

6. D.D. Krykanov, Public-Private Partnership, 4(3) (2017) doi: 10.18334/ppp.4.3.38449

7. R. Wettenhall, International Handbook in Public-Private Partnerships, Cheltenham UK: Edward Elgar (2010)

8. Matti Siemiatycki, Naeem Farooqi, Journal of the American Planning Association, 78 (3), 286-299 (2012) doi:10.1080/01944363.2012.715525

9. I. A. Vizhina, A.A. Kin, V.N. Kharitonova (2012) DOI: 10.1134/S2079970513010139

10. M. Bult-Spiering, G. Dewulf, Strategic Issues in Public-Private Partnerships: an International Perspective. Blackwell Publishing Ltd., 16-18 (2006)

11. Matti Siemiatycki, Naeem Farooqi, Journal of the American Planning Association, 78 (3), 286-299 (2012)

12. B. Eschenfelder, Nonprofit Management and Leadership, 21 (3), 273-288 (2011) doi: $10.1002 / \mathrm{nml} .20025$

13. Federal Law of July 13, 2015 No. 224-Federal law (as amended on July 26, 2019)

14. A. Berezin, B.S. Sergi, N. Gorodnova, Efficiency Assessment of Public-Private Partnership (PPP) Projects: The Case of Russia. Sustainability (Switzerland), 10(10), 3713 (2018) https://doi.org/10.3390/su10103713 
15. The World Bank Group - The Public- Private Infrastructure Advisory Facility. July 2008. [Electronic resource] http://ppi.worldbank.org.(Date of access:12.10.2019). 